\title{
ACCESSIBILITY: CLOSED CAPTION, BRAZILIAN SIGN LANGUAGE (LIBRAS), AUDIO DESCRIPTION AND UPDATING OF STANDARDS
}

\section{Chair: Caio Augusto Klein - Gerente Executivo de Operações da RBSTVI SET}

The issue of accessibility is increasingly present in the daily lives of broadcasters. According to IBGE, $6.2 \%$ of the Brazilian population (13 million people) have some type of disability. In recent years, Brazilian legislation is advancing inclusion measures so that everyone has access to information, culture and leisure. This panel will address the issue of accessibility in all its forms as closed captioning, Libras (Brazilian Sign Language), audio description, and also present the rules governing the adoption of these services by broadcasters. We will present practical solutions implemented and discuss the technologies available in the market.

- ACCESSIBILITY: CONCEPTS AND RULES Speaker: Luiz Fausto - Regulatory Strategy Specialist for Globo TV Network In this speech, we will present the fundamental concepts of accessibility in television, as well as the rules governing the provision of such services in the Brazilian broadcast television.

- SOLUTIONS FOR CLOSED CAPTION Speaker: Raphael Oliveira Barbieri - Gerente de Produtos EiTV Entretenimento e Interatividade para TV Digital

To meet the growing demand for hidden caption generation, new technologies for the generation of this content are increasingly necessary.. This lecture will address the advantages and disadvantages of Voice Recognition and Stenotype systems, what software and hardware solutions are required, and examples of scenarios for the generation and transmission of Closed Caption in the baseband (SD / HD-SDI) and compressed (ISDB-Tb distribution). 
- CLOSED CAPTION, LIBRAS AND AUDIO DESCRIPTION ON LIVE PROGRAMMING

\section{Speaker: Leandro Duarte Fernandes - General Programming Coordinator, RBS TV}

Leandro Fernandes presents the Case Debate RBS TV RS during the 2016 elections. A simultaneous broadcast of 12 debates, with features of closed caption, Libras and audio description.

- INFRASTRUCTURE FOR ACCESSIBILITY

\section{Speaker: Marcos Luis Padeti Junior - Coordenador técnico - Record TV}

Infrastructure approach to provide accessibility features and framework requirements in standards guidelines. Work scenarios as a main station.

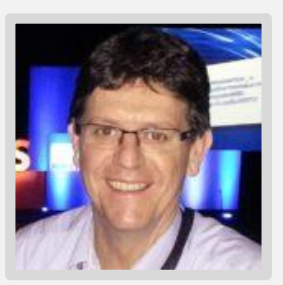

\section{Caio Augusto Klein - Gerente Executivo de Operações da RBSTV/ SET}

Electrical engineer graduated at UFRGS (Federal University of Rio Grande do Sul), post graduated in Business and People Strategic Leadership at ESPM-RS. Initiated his career at RBS as the Technical Coordinator of RBSTV Uruguaiana. Afterwards, he returned to Porto Alegre, where he worked in projects of RBS new facilities, such as RBS Video São Paulo and RBSTV Santa Cruz. Then, for 10 years, Caio was the Technical Director of TVE-Rio Grande do Sul. In 2005, he returned to RBS to be the Technical Manager of the Group's radio stations. During this time, he participated on the news coverage of the 2006 and 2010 FIFA World Cups, the 2008 Summer Olympic Games and the 2006 and 2010 FIFA World Cup Clubs, events where he was responsible for the RBS Group's logistic. In 2009, Caio returned to RBSTV Porto Alegre as the Operations Executive Manager and also participated on big coverages, like the 2014 Brazil's FIFA World Cup.

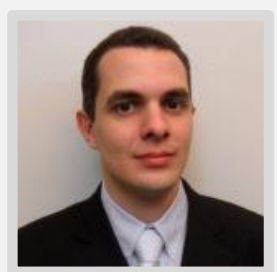

\section{Luiz Fausto - Especialista em Estratégia e Regulatório da Rede Globo}

Professional Master's Degree in Applied Computing (UECE - 2015), Executive MBA on IT (UFRJ - 2011), extension course in Networks and Video over IP (UFRJ - 2009), Bachelor's Degree in Electrical Engineering with emphasis in Electronics (UFRJ/USU - 2005). Currently working as Regulatory Strategy Specialist for Globo TV Network, Deputy Director of the Technology Board Committee of the Brazilian Television Engineering Society (SET), member of the Delegation of Brazil in ITU-R (SG 6) and CITEL (PCC.II), member of the TV Reception Technical Group (GT-Rx) of the Brazilian TV Switch-Over Group (GIRED), member of the Technical Module of SBTVD Forum and member of the Harmonization Working Group of ISDB-T International Forum. 


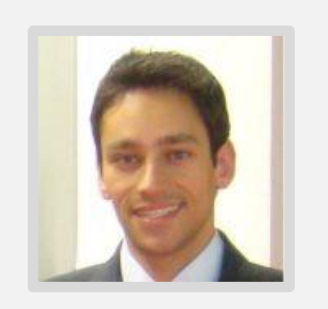

\section{Raphael Oliveira Barbieri - Gerente de Produtos EiTV Entretenimento e Interatividade para TV Digital}

Raphael Barbieri holds an MBA in Project Management from FGV (2014) and holds a degree in Computer Engineering from UNICAMP (2007) with emphasis on industrial systems and processes. $\mathrm{He}$ is currently studying for the Electrical Engineering Faculty of UNICAMP, Member of the Technical Module of the SBTVD Forum and Product Manager of EiTV, where he works since 2007 with the study and development of new hardware and software technologies for the Brazilian digital TV system ( SBTVD)

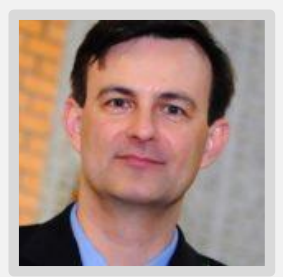

\section{Leandro Duarte Fernandes - General Programming Coordinator, RBS TV}

Leandro Fernandes holds a Bachelor's Degree in Business Administration from PUC-RS with an MBA in Production Engineering with emphasis on Innovation and Quality from UFRGS. He has solid experience in maintenance, engineering and operations with 18 years of experience in television stations. Already managed areas of Technology, Network Expansion and Administrative. $\mathrm{He}$ is currently responsible at RBS TV RS for the General Coordination of Programming and Exhibition.

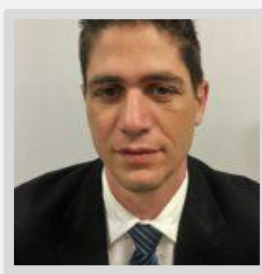

\section{Marcos Luis Padeti Junior - Coordenador técnico - Record TV}

Bachelor in Industrial Design with emphasis on product design by Oswaldo Cruz (2005) and Management of Information Technology (2014) extension in Project Management by FIAP (2017). Coordinator of systems of exhibition, 14 years in Record TV, always in the department of programming and exhibition, working with project development, market analysis and maintenance. 